\title{
THE STUDY OF BIOLOGY PRACTICUM MODEL IN INSTITUTE OF TEACHER EDUCATION (ITE)
}

\author{
Paramitha Cahyani ${ }^{1}$, Aloysius Duran Corebima ${ }^{2} *$, Siti Zubaidah ${ }^{1}$, Susriyati Mahanal ${ }^{1}$ \\ ${ }^{1}$ Universitas Negeri Malang, Malang, Indonesia \\ ${ }^{2}$ Universitas Kanjuruhan Malang, Malang, Indonesia \\ *e-mail: durancorebima@gmail.com
}

\begin{abstract}
Practicum activities are inseparable components in learning biology. This research aims at revealing variety of practicum models designed by lecturers and the factors that influence their decisions to implement particular practicum models in their biology learning in ITE. The research was conducted for two semesters, involving 72 lecturers in 6 ITEs in Jember and Malang, Indonesia. The data were collected using interview method and document analysis. The results of this research revealed that the practicum model commonly implemented by the respondents were cooking recipe based practice model. This research also revealed that the current practicum structure does not have much development or difference from the practicum structure found in the previous studies. Although this practicum model has several disadvantages, the cooking recipe based practice model results in relatively good achievement of biology learning outcomes.
\end{abstract}

Keywords: biology practicum, biology learning, cooking recipe based pratice, practicum model.

\section{PENELITIAN MODEL PRAKTIKUM BIOLOGI DI LEMBAGA PENDIDIKAN TENAGA KEPENDIDIKAN (LPTK)}

\begin{abstract}
Abstrak: Kegiatan praktikum merupakan komponen yang tidak dapat dipisahkan dalam pembelajaran biologi. Penelitian ini berusaha mengungkap beragam model praktikum yang dirancang oleh dosen serta faktor-faktor yang mempengaruhi keputusan mereka dalam menetapkan model praktikum tertentu pada pembelajaran biologi di LPTK. Penelitian dilakukan selama dua semester pada 72 dosen di 6 LPTK di kawasan Jember dan Malang Kota. Pengambilan data menggunakan metode wawancara serta analisis dokumen. Hasil penelitian mengungkap bahwa praktikum yang diterapkan oleh responden masih bermodel cooking recipe based pratice. Temuan ini mengungkap bahwa pola praktikum yang berjalan saat ini tidak mengalami banyak perkembangan dari hasil temuan penelitianpenelitian sebelumnya. Model praktikum ini memiliki beberapa kekurangan, namun dianggap masih layak untuk dijalankan. Selain itu, temuan pada studi ini turut mengungkap bahwa cooking recipi based pratice menghasilkan pencapaian hasil belajar biologi yang relatif baik.
\end{abstract}

Kata Kunci: praktikum biologi, pembelajaran biologi, cooking recipi based pratice, model praktikum

\section{INTRODUCTION}

Teachers and teacher education play an important role in improving educational systems, learning success, and positive changes in the social environment (Darling-Hammond, 2000; Davids, 2015; Endeley, 2014). Good teacher education is considered to produce quality teachers who are able to give contribution on the development of good education system (Endeley, 2014). In the broader domain, good education is also a major factor determining the success of the development of nations (United Nations Educational Scientific and Cultural Organization, 2005). In Indonesia, the implementation of teacher education is organized by the Institute of Teacher's Education (ITE).
Practicum is a key component in teacher education. Some educators stated that teacher training education was actually built by practical conditions compared to the theoretical and technical understanding, so that all theoretical understanding should be realized in a practical condition (Gujjar et al., 2010; Hastings, 2010). Practical activities are also seen as constructivist steps to become professional teachers (Kemmis, 2009; Luo \& Xu, 2019), and the knowledge needed by pre-service teachers can be trained with activities (Eraut, 2006; Szklarski et al., 2008).

Biology is both a theoretical and a practical science (Assinder et al., 2010). Biology learning requires practical activities which are essential components in order to deepen the 
understanding of the theories that have been learned (Assinder et al., 2010). Practicum activities provide students the understanding of the biological sciences through observation and experimentation, develop coherent thinking, and provide various other benefits including increasing creativity, curiosity, critical thinking and problem solving, supporting collaborative skills, fostering active learning and integrating knowledge in the form of practicum results (Allen, 2009; Assinder et al., 2010; Darling-Hammond, 2000).

Several studies conducted by Kivunja (2015), Piantola et al. (2018), and Timmis et al. (2019) indicate that practicum activities have not maximally empowered students' thinking skills. In addition, other research findings indicate that practicum has small contribution towards the students' skills in solving real world problems (Biggs \& Tang, 2011; Lent \& Brown, 2006; McCune \& Entwistle, 2011; G. Rutherford, 2016; Yayli, 2008). Moreover, Meijer et al. (2011) show that there is a huge gap between the theoretical lecturing and practicum the preservice teachers received. The gaps in the integration of theory and practice is due to the ignorance of educators regarding to the practical learning (Beck \& Kosnik, 2002; Bullough, 2008) and the lack of pedagogical understanding (Yan $\& \mathrm{He}, 2010)$. As a matter of fact, a teacher education cannot run well without an effective practicum activities (Salawu et al., 2008).

Roness (2011), Cochran-Smith (2005), and Korhagen (2010) also stated that the lack of practical experience in ITE learning had an effect on the teaching professionalism of the ITE graduates. In fact, the right practicum activities can provide benefits in terms of reviewing, renewing and improving the learning (Wimmer, 2008; Wyss et al., 2012). The practicum activites which are carried out using diverse approaches and strategies play a role in bridging the theoretical understanding in all majors including in the teacher education (Levine, 2006; Vick, 2006).

The practicum activities carried out at most levels of education, from High School levels to university level, still use manuals or cooking recipe based guidelines (Jayanti, 2018; Maknun, 2012). The results of observations on the practicum manual structure of various ITEs that were accessed online show that many universities still using very directive practicum guidelines.. The cooking recipe based practice is indeed classified as a traditional practicum, limited to technical knowledge, not supporting the formation of the character of the pre-service teachers, and not having significant contribution toward the improvement of students' thinking skills (Darling-Hammond, 2000; Rustaman, 2002; Schulz, 2005). Rustaman (2002) and Buku et al. (2016) stated that the practicum activites using cooking recipe model which were conducted at various universities did not empower students' thinking skills. However, the reasons and benefits of using cooking recipe based practice have not been completely revealed. Therefore, it is still implemented at biology education study program in many universities, including at ITEs.

The implementation of a particular model in the practicum activities in a department at higher education can be expected as the effect of variations in economic, political, and professional conditions of the educator himself (DarlingHammond, 2000). The determination of a practicum model also depends on the conditions of each institution including the range of lectures, time allocation, student conditions, and various other factors (Zeichner \& Conklin, 2008).

The need for practicum activities which can provide greater benefits in learning requires an analysis of various practicum models in the field. The results of the analysis can be useful in providing an overview to review, improve, renew, develop, and/or enhance the practicum activities in higher education (Loughran, 2004; Wimmer, 2008). A study investigating the practicum model used in various universities involves the reasons for using a particular practicum model, the general picture of the practicum model, the implementation of the practicum activities, various supporting documents used in the practicum activities, or the other supporting factors that can provide a general picture regarding the practicum model in ITEs needs to be conducted. Therefore, we are interested in conducting a study on the Biology Practicum Model in ITEs.

\section{METHODS}

This research is a qualitative research (Creswell \& Poth, 2016; Merriam \& Tisdell, 2015) where it has clear research limitation (Asmussen \& Creswell, 1995) and is carried out in a predetermined period of time, location, sample and collection process (Stake, 1995; Yin, 2009, 2017). This research aims at exploring the practicum models used in 6 ITEs in Jember district and Malang City from the even semester 
of the 2017/2018 academic year to the odd semester of the 2018/2019 academic year.

\section{Participants}

The research samples were selected by using purposive sampling technique, meaning that the samples were chosen by the researcher, with a particular consideration that the selected samples could represent the research conducted (Cohen et al., 2002). The participants were the lecturers who designed biology practicum activities carried out in each ITE with a total of 72 respondents consisting of 43 female and 29 male persons from 6 ITEs in Jember and Malang City with different educational backgrounds as presented in Table 1.

Table 1. Information about the respondents

\begin{tabular}{lcc}
\hline Gender & f & $\%$ \\
\hline Male & 29 & 41 \\
Female & 43 & 59 \\
\hline Educational Background & & \\
\hline Master in Biology Education & 41 & 56.9 \\
Doctor in Biology Education & 3 & 4.2 \\
Master in Biology (Molecular Biology, & 20 & 27.8 \\
Ecology, etc) & & \\
Doctor in Biology (Molecular Biology, & 3 & 4.2 \\
Ecology, etc) & 5 & 6.9 \\
Master in Other Fields & 0 & 0 \\
Doctor in Other Fields & & \\
\hline Teaching Experience & 0 & 0 \\
\hline Less than 1 year & 32 & 44.4 \\
1-2 years & 29 & 40.3 \\
2-3 years & 11 & 15.3 \\
\hline More than 3 years & & \\
\hline
\end{tabular}

Each respondent participated in designing the practicum including practicum activities as well as practicum guide books/documents for 23 different lectures/subjects. The distribution of lectures taught by the respondents is presented in Table 2.

\section{Data Collection Technique}

The research data were collected as follows. Initially, the implementation of the practicum activities that usually implemented were observed. After that, the supporting documents of the practicum activities were analyzed including the practicum guidebooks, module, and the other supporting documents. Finally, the respondents were interviewed using the key questions used in this research. The results of the interview were guided to form a personal narration of the respondents towards the research questions. The interview in this research used semi-structured interview (East et al., 2009; Wijaya et al., 2020) that was conducted through a face-to-face interview (Creswell, 2012) using the main question to achieve the expected objectives (Hanifah \& Irambona, 2019; Marshall \& Rossman, 2014). After that, the three types of the data were analyzed to form various themes that emerged based on the research findings.

\section{Table 2. Distribution of subjects of} respondents

\begin{tabular}{lc}
\hline \multicolumn{1}{c}{ Subject of Respondens } & f \\
\hline Microbiology & 4 \\
Plant Taxonomy & 3 \\
Animal Taxonomy & 3 \\
Plant Structure and Development & 5 \\
Plant Ecology & 3 \\
Ecology & 4 \\
Basic Natural Sciences & 2 \\
Plant Systematics & 1 \\
Genetics & 6 \\
Animal Physiology & 4 \\
Evolution & 4 \\
Human Anatomy and Physiology & 3 \\
Plant Morphology & 4 \\
Plant Anatomy & 2 \\
Agricultural Science & 1 \\
Animal Physiology & 6 \\
Agriculture Ecology & 1 \\
Vertebrate & 3 \\
Basic Biology & 8 \\
Cell Biology & 4 \\
Animal Structure and Development & 3 \\
Histology & 2 \\
Embriology & 2 \\
Total & \\
\hline
\end{tabular}

\section{Data Analysis}

The supporting documents of the practicum activities were analyzed by referring to the parameters of cooking recipe based pratice by (Sugiharto et al., 2018). The technical parameters formulated by Sugiharto et al. (2018) in helping researcher to analyze the supporting documents include: the practicum instructions, the grouping, the uniformity of practicum topics, the target of evidence and discovery, the research title, the formulation of practicum objectives, the practicum procedures, the data analysis guidelines, the reports, the characteristics the reports, and the publication of lab results (posters), as well as practicum report seminars. Moreover, the data collected from the interviews were subsequently identified and analyzed by rereading it, making notes from it, and catagorizing it by particular groups (coding) (Rallis \& Rossman, 2012) which was later developed to form a particular theme (Conrad \& De Four-Babb, 2013; Creswell, 2012). The results of the interview were process- 
ed by rewriting what had been recorded, then determining the coding based on these results (Creswell, 2013; Miles et al., 2014). The themes that emerged were then identified, connected to each other, and described in the form of qualitative reports. The final step in the data analysis is to interpret the results of the research (Creswell, 2013). The data from the interview were deductively analyzed and then combined with the supporting documents as a form of theoretical thematic analysis (Braun \& Clarke, 2006; Patton, 2002).

\section{Research Limitation}

This research was only limited to digging up information related to the practicum model designed by the respondents. The researcher was not involved in either the designing of the practicum model or the implementation of the practicum model. In addition, like many studies involving respondents, there may be a bias in which participants may present biased views regarding the questions posed. Some participants may have revealed all aspects related to the implemented practicum model, but some others may not be able to open up to the interviewers. Overall, the results and findings of this research have shown balanced results regarding the reasons and benefits of using a particular practicum model.

\section{FINDING AND DISCUSSION}

\section{Finding}

This research was carried out on 72 respondents by conducting interviews, observation, and document analysis related to the practicum structure and the reasons underlying the determination of a particular practicum model. The findings of this research are presented further.

The implemented curriculum

The curriculum used by the respondents to design lecture activities and practicum activities is the KKNI curriculum (Indonesian National Qualification Based Curriculum). The practicum activities were designed by referring to the learning objectives and were aimed to support the achievement of the learning objectives.

The implementation of the practicum activities

The practicum was implemented throughout the semester with duration of 4-5 months with the support of the practicum guide books. The practicum was carried out every week by following the themes provided in the practicum guide book. The activities in the practicum have been clearly described in the practicum guide book, including the stages of the activities, data collection steps, to reporting procedures, and the students just needed to follow the instructions provided in the guide book. At the end of the lecture period, response activities in the form of examinations were carried out, mostly written examinations and these findings were relatively similar among all respondents.

The overview of the supporting documents of the practicum activities

There were 3 types of supporting documents of the practicum activities used in the ITEs in Jember City and Malang City, namely practicum guidebooks, practicum modules, and practicum observation sheets. All of these supporting documents have similar characteristics, which is having clear overview related to the operational instructions and practicum activities. The distribution of the supporting documents of the practicum activities is presented in Table 3 .

The results of the supporting document analysis show that in general the practicum carried out by respondents were still supported with practicum instructions, either in the form of practicum guidebook, module, or practicum worksheet.

\section{Overview of practicum groups}

All of the practicum activities designed by the respondents were in the form of group practicum. The groups were mostly big groups consisting of 4-5 students in each group. The distribution of the member number of the practicum groups designed by the respondents can be seen in Table 4 .

Overview of publications and seminar of the practicum results

The research findings reveal that related to the seminar parameter, the published result practicum were only $9.1 \%$. Meanwhile, there were not any publications of the practicum results carried out in ITEs. The overview of the publications and seminar of practicum results can be seen in Table 5 .

\section{Analysis of practicum supporting documents}

In this research, the parameters of the lab report characteristics and the target of evidence and discovery in the practicum were not used. The recapitulation of the results of supporting document analysis associated with the technical parameters used is presented in Table 6. 
Table 3. The Distribution of supporting documents of practicum activities in ITEs

\begin{tabular}{|c|c|c|c|}
\hline \multirow{2}{*}{ Lecture } & \multicolumn{3}{|c|}{ Types of supporting documents } \\
\hline & Practicum guidebooks & Practicum modules & Practicum observation sheets \\
\hline Microbiology & $\sqrt{ }$ & & \\
\hline Plant Taxonomy & & & $\sqrt{ }$ \\
\hline Animal Taxonomy & & & $\sqrt{ }$ \\
\hline Plant Structure and Development & & & $\sqrt{ }$ \\
\hline Plant Ecology & $\sqrt{ }$ & & \\
\hline Ecology & $\sqrt{ }$ & & \\
\hline Basic Natural Sciences & & $\sqrt{ }$ & \\
\hline Plant Systematics & $\sqrt{ }$ & & \\
\hline Genetics & $\sqrt{ }$ & & \\
\hline Animal Physiology & $\sqrt{ }$ & & \\
\hline Human Anatomy and Physiology & & & $\sqrt{ }$ \\
\hline Plant Morphology & & & $\sqrt{ }$ \\
\hline Plant Anatomy & & & $\sqrt{ }$ \\
\hline Agricultural Science & & $\sqrt{ }$ & \\
\hline Animal Physiology & $\sqrt{ }$ & & \\
\hline Agriculture Ecology & & $\sqrt{ }$ & \\
\hline Vertebrate & $\sqrt{ }$ & & \\
\hline Basic Biology & $\sqrt{ }$ & & \\
\hline Cell Biology & $\sqrt{ }$ & & \\
\hline Animal Structure and Development & & & $\sqrt{ }$ \\
\hline Histology & & & $\sqrt{ }$ \\
\hline Embriology & $\sqrt{ }$ & & \\
\hline Percentage $(\%)$ & 50 & 13,6 & 36,4 \\
\hline
\end{tabular}

Table 4. Distribution of the number of group members in the practicum activities in ITEs

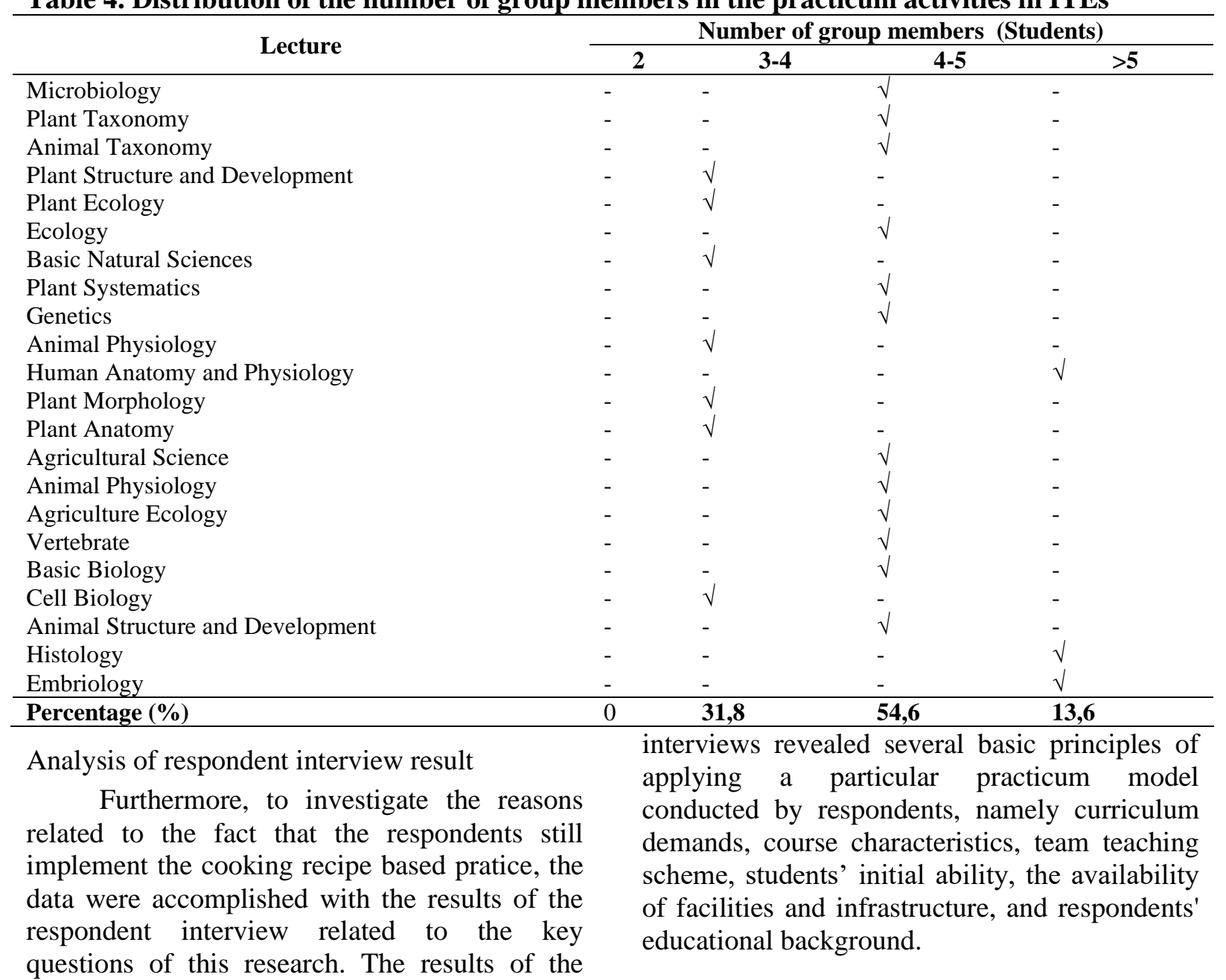


Table 5. Overview of publications and seminar of the practicum results in ITEs

\begin{tabular}{lcc}
\hline & \multicolumn{2}{c}{ Seminar and Publications of practicum results } \\
\cline { 2 - 3 } Microbiology & Seminar of practicum results & Publications of practicum results \\
Plant Taxonomy & - & - \\
Animal Taxonomy & - & - \\
Plant Structure and Development & - & - \\
Plant Ecology & - & - \\
Ecology & $\sqrt{ }$ & - \\
Basic Natural Sciences & - & - \\
Plant Systematics & - & - \\
Genetics & $\sqrt{ }$ & - \\
Animal Physiology & - & - \\
Human Anatomy and Physiology & - & - \\
Plant Morphology & - & - \\
Plant Anatomy & - & - \\
Agricultural Science & - & - \\
Animal Physiology & - & - \\
Agriculture Ecology & - & - \\
Vertebrate & - & - \\
Basic Biology & - & - \\
Cell Biology & - & - \\
Animal Structure and Development & - & - \\
Histology & - & - \\
Embriology & - & - \\
\hline Percentage (\%) & 9,1 & - \\
\hline
\end{tabular}

Table 6. Recapitulation of practicum supporting document analysis

\begin{tabular}{lc}
\hline Parameters & $\%$ \\
\hline Unifornity of Practicum & 100 \\
Practicum Title & 100 \\
Practicum Objective & 100 \\
Practicum Procedures & 100 \\
Guidelines for Data Analysis & 46,1 \\
Practicum Reports & 100 \\
\hline
\end{tabular}

\section{Discussion}

The results of this research which involved observation, document analysis, and interview reveal that the practicum activities at the ITEs in Jember and Malang are still following cooking recipe based pratice. The definition of the cooking recipe based pratice refers to Sugiharto et al. (2018). It is the practicum activity which uses a practicum guidebook, which is generally very directive, beginning from the title, objectives, working procedures, to data analysis methods. The results of the supporting document analysis show that in general the practicum carried out by respondents were still supported with practicum instructions, either in the form of practicum guidebook, module, or practicum worksheet. The general structure of practicum instructions illustrated from the results of the analysis was that there was a practicum title, the objectives of the practicum, the tools and materials used, and the procedures of the practicum. The results of the data interpretation in Table 3 until 6 show a very clear picture that the practicum guideline is a form of guidance on all practicum activities, which also fulfill the points included in the parameter. The results of the research related to the practicum model have not met the expectation to improve the quality of learning and the effectiveness of teacher education as stated by Cochran-Smith (2006) and Larrabee and Morehead (2010). The current structure of the practicum is not in line with the statement by Brewer (2006) that teacher education is an important foundation in the advancement of education in the future. With the results obtained from the implementation of cooking recipe based pratice today, it can be said that it does not really support Brewer's statement (2006).

This research also attempted to find out the themes from the survey data leading to the main question namely: What are the basic principles of 
the implementation and the practicum structure which are currently applied.

All respondents agreed that the implementation as well as the practicum structure they designed were the result of adjustments to the applied curriculum and syllabus. The current Indonesian National Curriculum also brings changes to the course structure and practicum activities, although the focus of the changes revolves around the topics for the practicum activities rather than on particular models. The curriculum demands that affect the implementation of practicum with certain models are only seen when faced with the competency to operate certain tools or materials. The practicum activities for the subjects whose sub-material distribution requires the mastery of operating certain tools are considered to be easier to be carried out using cooking recipe structure. This is because with the nature and the characteristics of the tool and material, its utilization cannot possibly be explored without the appropriate application. The practicum activities designed by the respondents involved the formation of practicum groups with more than two members, with an average of 4-5 members like as illustrated in Table 4 and this was considered ideal according to the respondents. This condition is different from what is stated by Corebima (2018) that the ideal composition of a practicum group is 2 members. This statement by Corebima (2018) is supported by Rutherford (2016) stating that the groups that have more members tend to have lower collaboration than the groups having fewer members, in this case, it can refer to groups of only 2 members. (S. M. Rutherford et al., 2016) revealed that when there were too many members in a group, the potential for distraction in completing the task will be greater due to the many branching thoughts of each member, causing the potential for collaboration to be lower. The use of small groups can in fact increase students' productivity in solving problems and understanding topics (Gaytan \& McEwen, 2007). It encourages equal contributions among group members (Finegold \& Cooke, 2006), and provides a better learning experience for the students which results in better academic achievement (Springer et al., 1999). The preliminary findings by Brindley, Brindley et al. (2009) also support the advantages of small groups, where students actually prefer to work in small groups, so that the students' collaborative potential is possibly better than that of the students in large groups, although it also needs control over the performance of each group (Swan et al., 2019). The respondents' decision to conduct a practicum in large groups was influenced by the availability of the facilities and infrastructure as well as the efficiency from the respondents' perspective. The use of small groups was considered to make the assessment process difficult because not all practicum activites were assisted or facilitated by practicum assistants, so that with a smaller number of groups (in the form of large groups), the respondents felt that the assessment process would be easier and more efficient. The limitations of facilities and infrastructure also contributed to the formation of large groups as the most likely alternative.

In addition, another result that is of concern is that this research shows the low results related to the parameter of the seminar of the practicum results and the absence of the publication of practicum results. The final stage of the practicum activities is in the form of reports of the practicum results only, and there are no further stages. In this research, the seminar of the practicum results was carried out in the form of presentation of the practicum results, and only $9,1 \%$ of respondents did it. This low fact is also influenced by the characteristics of the courses/subjects as what previously revealed. Some subjects, such as Plant Development Structure, Plant Morphology, Anatomy and Human Physiology are carried out in the form of observation activities, so that seminars or presentation of the practicum results are considered unnecessary. Meanwhile, the efforts to publish the practicums results have not been empowered. These findings also underline the statement that there have not been any significant differences/ improvements in the practicum model in the last decades. (Rustaman, 2002) stated that the cooking recipe based pratice model was only for verifying certain objectives. This model is considered to not provide opportunities for students to discover something new in biology. However, the reality in the field shows that this model continues to be used without any significant changes/improvements, so that it is considered essential to to improve the practicum activities in the future.

The next factor that plays a role in the implementation of certain practicum structures/ models is the team teaching scheme. The team teaching in this research is more related to the form of team coordination, where two lecturers or more share the same lesson plan for the whole students but the classroom teaching is still indivi- 
dually done, in separate classes or in separate of class meetings (Goetz, 2000). The team coordination also influences the determination of the practicum models, in addition to the fact that theory learning and practicum activities are two interrelated things (Allen \& Wright, 2014; Schon \& DeSanctis, 1986; Taguchi, 2007). Team teaching can actually be advantageous, especially to producing new teaching approaches as the results of the coordination done (Goetz, 2000), enabling the completion of more efficient work (Mohamed et al., 2012); a team teaching often has several teachers with different field characteristics that allow cross-disciplinary discussion (Johnson et al., 2000) (Benjamin, 2000; Gibson et al., 2007). The respondents acknowledged that the scheme of team teaching could complete the concept that emerged from one team member, where the other team members could see the concept and overcome the weaknesses. Team teaching provides collaborative experiences that can maximize students' learning outcomes (Duimering \& Robinson, 2009; Stewart, 2005). However, in addition to these advantages, team teaching scheme also reduces their independence and idealism in determining the pattern of appropriate practicum for the students because they have to "share" their thoughts with other lecturers in determining the practicum structures and teaching patterns. (Jaruda \& Takeuchi, 2007) also revealed that the team-teaching scheme could also have an impact on the disharmony of the team members due to the differences in perspectives between each member. However, it is also stated that when there is a 'seniority' in a team teaching, the presence of senior lecturers in a team teaching, normally the practicum structure implemented is in accordance with the views of the senior lecturers, and the other lecturers in the team follow that view.

In addition to the practicum structure, the form of the team teaching also influence the topics of the practicum taken. The differences in the educational background of the lecturers also influence the topics that are considered necessary to be included in the practicum activities. The respondents whose masters or doctors are in the field other than biology education also proposed the practicum topics based on their learning experience. The respondents whose masters or doctors are in education background revealed that the selection of practicum topics was based more on the students' needs as the future biology teachers. The curriculum applied in high schools is a further consideration for the lecturers in selecting the topics for practicum activities. The selected topics for practicum are also adjusted to the practicum topics in high schools, so that the practicum carried out is a form of training for the pre-service teachers in order that they could conduct practicum activities in the schools where they would work in the future.

The determination of the practicum topics is also influenced by the lecturers' interest, so that the selected practicum topics are more focused on the topics that the lecturers truly master. For example, the respondents whose education background is biology with ecology concentration, they tended to conduct practicum activities with the material of genetics based on the environment or associated with ecology when teaching genetic course,. These results are in line with the statement by Leavitt and Shneiderman (2006) that every educator tends to teach according to his field of study, so that the teaching topic is often limited to the topic that the educator masters. This is also supported by Klein (2008), that teachers (in the context of this research are lecturers) have the opportunity to show their personality, while providing variations in terms of topics of practicum even though the practicum structure is carried out using cooking recipe based pratice.

The next factor underlying the implementation of the cooking recipe practicum structure was the consideration of some respondents regard-ing their students' initial abilites, especially those in non-state ITEs who assumed that the students had lower initial academic abilities. The respondents assumed that the students were not ready to be given an independent practicum design. The respondents thought that the students still needed to be directed about what they had to do in the practicum activities. However, some respondents did not consider students' initial ability in determining the structure of the practicum, while the remaining respondents stated that they had considered the students' initial ability factor but did not do further evaluation regarding this matter. The lack of in-depth evaluations by the respondents, especially regarding with what kind of practicum suits the students best, can have an effect, such as, there is not any improvement in the students' skills as reported by (Bogo et al., 2007; Furness \& Gilligan, 2004), as well as (Jervis \& Tilki, 2011). However, the influence of the limited facilities and infrastructure factor that had previously been revealed was more on the limited practicum topics and did not influence the determination of practicum models. 
The next main theme that the researcher wanted to explore in this research is the advantages of the cooking recipe based pratice, so that this model is chosen and maintained for several periods of time. Cooking recipe based practice forms better collaboration in terms of work division. Clear practicum stages are considered to make it easier for students to share work to complete the activities. This structure can also be considered as a setting that is used for students to practice scientific skills and scientific activities. A complete and structured guide to this model is also considered more ideal for low academic ability students because they can directly take part in the activities. The next advantage agreed by all respondents is that this practicum model makes it easier for lecturers to conduct the practicums because the lecturers do not need to explain and assist students all the time, and it makes the assessment process easier.

The cooking recipe based pratice is chosen to be implemented because of the assumption that this model does not only prove a theory. The respondents considered that to prove a theory, a series of scientific activities is also needed. Although it uses a directive practical guideline, but its implementation is still deep and complex, including disciplinary processes, collaboration, knowledge of tools, materials, mastery of certain conditions, knowing the philosophy of design and analysis, character as well as interpretation and reports.

The reflection carried out in this research also raises a statement that the practicum model implemented still has various weaknesses and requires evaluation and revision. Cooking recipebased practice appeared to increase students' activity, but the essence of the implementation of the practicum had not given significant contribution toward the overall learning outcomes. Similar results were also reported by (Korthagen, 2010; Seferoğlu, 2006), and van Hout-Wolters et al. (2000). This is certainly contradictory to the importance of practicum according to Yan \& $\mathrm{He}$ (2010) that practicum should bridge the shortcomings that might arise from theoretical learning, and (Davids, 2015; Dawson \& Dana, 2007; Evans, 2004; Wentworth et al., 2008), stating that practicum is integrated with theoretical learning and should complement one another. It was also revealed that the current practicum structure did not have a contribution toward the better learning results. The cooking recipe based pratice is also considered to be unable to maximize the potential of students' thinking skills because the whole activities are already instructed in the practicum guidelines, so that the students do not need to think further about the 'goals' of what they will obtain from the practicum process. Other respondents also emphasized the need to establish a new practicum structure with a challanging task-based practicum structure or which is designed with the aim of improving students' thinking skills. The reflection also reveals that the student's final scores are still low. It is assumed that this occured because the practicum activities do not have a significant contribution toward the improvement of students' mastery.

The emergence of various results and basic principles in this research provides a broader learning and view regarding the background that underlies the selection of a particular practicum structure in a teacher education institution. This difference of views needs to be appreciated, as stated by Griffiths (1992) that an appreciation is needed for every thought produced by practitioners, and the thought will develop along with the evaluation carried out, although ideally educators are obliged to organize learning (including practicum) and evaluations that are capable of producing competent teacher candidates (Boley \& Whitney, 2003; Chui, 2016; Redmond \& Bright, 2007), including the decision to conduct practicum using certain models. The purpose of Biology education as well as teacher education in general is to improve the knowledge, skills and attitudes of the pre-service teachers, and practicum activity is an effort to provide real experiences related to this goal (Tuli \& File, 2010). Practicum also has an effect on developing the character of the pre-service teachers because practicum is clearly more authentic than the theoretical learning.

Changes in practicum structure from traditional to a practicum with a broader focus are needed, that is a practicum experience that provides the opportunities for students to conduct investigations, to test new ideas, and to develop their knowledge instead of just testing their knowledge (Zeichner, 1993), but in the conditions that occured in this research, this model could also be considered as the ideal form of practicum which was most likely to be conducted. The variations in practicum forms can also be influenced by variations in professionalism, which is the competency of the lecturers themselves (Darling-Hammond, 2000). In this connection, it can be found in relation with the variation of the practicum conducted by lecturers who had a linear academic background and those 
who did not have a linear academic background. Thus, it was assumed that there was a difference in the lecturers' competency when they taught in biology education. The team teaching scheme may also result in competence variations among lecturers that eventually decide to implement the cooking recipe based practice model. In addition, the unavailability of facilities and infrastructure can also make cooking recipe based practice be the most possibble practicum model implemented.

In our opinion, the cooking recipe based pratice is not always disadvantageous. This practicum model is suitable for a number of conditions or topics related to the basic technical mastery, such as the skills of using certain tools. The use of guidelines can also provide the students with the initial knowledge and choices to determine the next steps in the practicum activities. The researcher also found that a practicum model should not be viewed from one perspective only, but it should be further studied related to the factors of these conditions, as what is stated by Wimmer (2008) that at though practicum is considered as the core of teacher training, thinking orientation cannot be based on focusing on the model only without paying attention to the other factors. This is supported by (Zeichner, 1993) that practicum is educative when it can help students develop their learning capacity to achieve learning goals. If the implementation of cooking recipe based pratice can achieve a number of specific learning goals, the researcher assumes that this type of practicum model is feasible to be used.

\section{CONCLUSION}

The implementation of practicum in ITEs is generally in the form of cooking recipe based pratice does not have any significant changes/ improvements from year to year, and it is still considered relevant to be implemented although many research findings show that the practicum model had many weaknesses. The implementation of cooking recipe based pratice is determined by a variety of factors, such as the curriculum demands, the characteristics of subjects/ courses, the team-teaching schemes, the students' initial ability, the availability of facilities and infrastructure, and the respondents' educational background. Based on the conditions found in this research, the coocking recipe based practice model cannot be seen as "surface touching practicum model", but it should be viewed as a practicum model which has the most probability to be implemented in biology learning, so the cooking recipe based practice is considered worthy yet to be applied.

Based on the results of this research, it is suggested that the practicum guidelines should be reformed into the more open inquiry-based model to accommodate higher order thinking skills, critical thinking, and creative problem solving.

\section{AKNOWLEDGMENT}

In this valuable occasion, researchers would like to express million thanks to the lectures from the 6 ITEs who have participated in this study.

\section{REFERENCES}

Allen, J. M. (2009). Valuing practice over theory: How beginning teachers re-orient their practice in the transition from the university to the workplace. Teaching and Teacher Education, 25(5), 647-654. https://doi.org/10.1016/j.tate.2008.11.011

Allen, J. M., \& Wright, S. E. (2014). Integrating theory and practice in the pre-service teacher education practicum. Teachers and Teaching, 20(2), 136-151. https://doi.org/10.1080/13540602.2013.84 8568

Asmussen, K. J., \& Creswell, J. W. (1995). Campus response to a student Gunman. The Journal of Higher Education, 66(5), 575-591.

https://doi.org/10.1080/00221546.1995.11 774799

Assinder, S., Jenkins, D., English, L., Adams, D., Levick, C., Bellingan, L., Hall, J., Devine, K., \& Burdass, D. (2010). Practical biology position statement the importance of practical biology: from school to higher education. In www.societyofbiology.org. Society of Biology.

Beck, C., \& Kosnik, C. (2002). Components of a good practicum placement: Student teacher perceptions. Teacher Education Quarterly, 29(2), 81-98.

Biggs, J., \& Tang, C. (2011). Teaching for quality learning at university (2nd ed.). McGrawHill Education. https://doi.org/10.1080/14703297.2013.83 9332

Bogo, M., Regehr, C., Power, R., \& Regehr, G. (2007). When values collide. The Clinical Supervisor, 26(1-2), 99-117. https://doi.org/10.1300/J001v26n01_08 
Boley, P., \& Whitney, K. (2003). Grade disputes: Considerations for nursing faculty. Journal of Nursing Education, 42(5), 198-203. https://doi.org/10.3928/0148-483420030501-05

Braun, V., \& Clarke, V. (2006). Using thematic analysis in psychology. Qualitative Research in Psychology, 3(2), 77-101. https://doi.org/10.1191/1478088706qp063 oa

Brewer, T. M. (2006). Teacher preparation solutions: Rumbling for quality just won't do. Studies in Art Education, 47(3), 269285.

https://doi.org/10.1080/00393541.2006.11 650086

Brindley, J., Blaschke, L. M., \& Walti, C. (2009). Creating effective collaborative learning groups in an online environment. The International Review of Research in Open and Distributed Learning, 10(3). https://doi.org/10.19173/irrodl.v10i3.675

Buku, M. N. I., Aloysius, D. C., \& Rohman, F. (2016). The correlation between metacognitive skills and the critical thinking skills of the senior high school students in biology learning through the implementation of problem based learning (PBL) in Malang, Indonesia. Int. Journal of Academic Research and Development, $1(5), 58-63$.

Bullough, R. V. (2008). Studies of teacher education and becoming and being $a$ teacher: Counter narratives. State University NY.

Chui, M. M. (2016). Private supplementary tutoring: motivations and effects: A review study. Journal of Education and Practice, 7(27), 195-198.

Cochran-Smith, M. (2006). Policy, practice, and politics in teacher education: Editorials from the Journal of Teacher Education. Corwin Press.

Cohen, L., Manion, L., \& Morrison, K. (2002). Research methods in education. Routledge. https://doi.org/10.4324/9780203224342

Conrad, D. J., \& De Four-Babb, J. (2013). Improving teacher education through a self-study of practicum programmes: Conversations and reflections of two teacher educators. School of Education, UWI, St. Augustine.
Creswell, J. W. (2012). Qualitative inquiry and research design: Choosing among five approaches. SAGE Publications.

Creswell, J. W. (2013). Educational research: Planning, conducting, and evaluating quantitative and qualitative research. Pearson.

Creswell, J. W., \& Poth, C. N. (2016). Qualitative inquiry and research design: Choosing among five approaches. Sage Publications.

Darling-Hammond, L. (2000). How teacher education matters. Journal of Teacher Education, 51(3), 166-173. https://doi.org/10.1177/002248710005100 3002

Davids, M. N. (2015). Teaching practicum assessment in post-apartheid teacher education: Is it self-serving or serving students? Journal of Education for Teaching, 41(4), 338-350. https://doi.org/10.1080/02607476.2015.10 80349

Dawson, K., \& Dana, N. F. (2007). When curriculum-based, technology-enhanced field experiences and teacher inquiry coalesce: An opportunity for conceptual change? British Journal of Educational Technology, 38(4), 656-667. https://doi.org/10.1111/j.14678535.2006.00648.x

Duimering, P. R., \& Robinson, R. B. (2009). Effects of context on team behaviour. International Journal of Human Resources Development and Management, 9(1), 1935. https://www.inderscienceonline.com/doi/a bs/10.1504/IJHRDM.2009.021566

East, K., Fitzgerald, L. M., \& Heston, M. L. (2009). Talking teaching and learning: Using dialogue in self-study. In Research Methods for the Self-study of Practice (pp. 55-72). Springer Netherlands. https://doi.org/10.1007/978-1-4020-95146_4

Endeley, M. N. (2014). Teaching practice in Cameroon: The effectiveness of the University of Buea model and implications for quality. Australian Journal of Teacher Education, 39(11). https://doi.org/10.14221/ajte.2014v39n11. 9

Eraut, M. (2006). Learning contexts. Wiley- 
Blackwell Publishing Ltd.

Evans, G. W. (2004). The environment of childhood poverty. American Psychologist, 59(2), 77.

Finegold, A. R. D., \& Cooke, L. (2006). Exploring the attitudes, experiences and dynamics of interaction in online groups. The Internet and Higher Education, 9(3), 201-215. https://doi.org/10.1016/j.iheduc.2006.06.0 03

Furness, S., \& Gilligan, P. (2004). Fit for purpose: issues from practice placements, practice teaching and the assessment of students' practice. Social Work Education, 23(4), 465-479. https://doi.org/10.1080/026154704200024 5053

Gaytan, J., \& McEwen, B. C. (2007). Effective online instructional and assessment strategies. American Journal of Distance Education, 21(3), 117-132. https://doi.org/10.1080/089236407013416 53

Goetz, K. (2000). Perspectives on team teaching: A semester I independent inquiry. EGallery, 1. http://people.ucalgary.ca/ egallery/goetz.h tml

Griffiths, C. E. M. (1992). A photonumeric scale for the assessment of cutaneous photodamage. Archives of Dermatology, 128(3), 347.

https://doi.org/10.1001/archderm.1992.016 80130061006

Gujjar, A. A., Naoreen, B., Saifi, S., \& Bajwa, M. J. (2010). Teaching Practice: Problems and Issues in Pakistan. International Online Journal of Educational Sciences, 2(2).

Hanifah, M., \& Irambona, A. (2019). Authentic assessment: Evaluation and its application in science learning. Psychology, Evaluation, and Technology in Educational Research, 1(2). https://doi.org/10.33292/petier.v1i2.4

Hastings, N. A. J. (2010). Physical asset management (Vol. 2). Springer.

Jaruda, K. M., \& Takeuchi, S. (2007). Team teaching: A step to a better students performance. Annual Report of the Faculty of Education, Gifu University. Retrived

$$
\text { July, 5, } 2016 .
$$

Jayanti, M. I. (2018). Implementasi model pembelajaran berbasis proyek untuk meningkatkan keterampilan berpikir kreatif mahasiswa. ORYZA ( JURNAL PENDIDIKAN BIOLOGI ), 7(2), 1-7. https://doi.org/10.33627/oz.v7i2.6

Jervis, A., \& Tilki, M. (2011). Why are nurse mentors failing to student nurses who do not meet clinical performance standards? British Journal of Nursing, 20(9), 582587. https://doi.org/10.12968/bjon.2011.20.9.58 2

Johnson, D. W., Johnson, R. T., \& Smith, K. A. (2000). Constructive controversy: The educative power of intellectual conflict. Change: The Magazine of Higher Learning, 32(1), 28-37. https://doi.org/10.1080/000913800096027 06

Kemmis, S. (2009). Action research as a practicebased practice. Educational Action Research, 17(3), 463-474. https://doi.org/10.1080/096507909030932 84

Kivunja, C. (2015). Exploring the pedagogical meaning and implications of the 4Cs "super skills" for the 21st Century through Bruner's 5E lenses of knowledge construction to improve pedagogies of the new learning paradigm. Creative Education, 06(02), 224-239. https://doi.org/10.4236/ce.2015.62021

Klein, S. R. (2008). Holistic reflection in teacher education: issues and strategies. Reflective Practice, 9(2), 111-121. https://doi.org/10.1080/146239408020053 84

Korthagen, F. A. J. (2010). How teacher education can make a difference. Journal of Education for Teaching, 36(4), 407423.

https://doi.org/10.1080/02607476.2010.51 3854

Larrabee, T. G., \& Morehead, P. (2010). Broadening views of social justice and teacher leadership: Addressing LGB issues in teacher education. Issues in Teacher Education, 19(2), 37-52.

Leavitt, M. O., \& Shneiderman, B. (2006). Based web design \& usability guidelines. Health and Human Services Department. 
Lent, R. W., \& Brown, S. D. (2006). On conceptualizing and assessing social cognitive constructs in career research: A measurement guide. Journal of Career Assessment, 14(1), 12-35. https://doi.org/10.1177/106907270528136 4

Levine, A. (2006). Educating school teachers. Education Schools Project.

Loughran, J. J. (2004). A history and context of self-study of teaching and teacher education practices. In International Handbook of Self-Study of Teaching and Teacher Education Practices (pp. 7-39). Springer Netherlands. https://doi.org/10.1007/978-1-4020-65453_1

Luo, Y., \& Xu, W. (2019). A review on the professional development of elementary education teachers in China. International Journal of Education and Learning, 1(2), 98. https://doi.org/https://doi.org/10.31763/ijel e.v1i2.56

Maknun, D. (2012). Praktikum ekologi berbasis proyek: Media pembekalan keterampilan esensial laboratorium. Jurnal Pendidikan MIPA (Old), 13(1). http://jurnal.fkip.unila.ac.id/index.php/JPM /article/view/396

Marshall, C., \& Rossman, G. B. (2014). Designing qualitative research. Sage publications.

McCune, V., \& Entwistle, N. (2011). Cultivating the disposition to understand in 21 st century university education. Learning and Individual Differences, 21(3), 303-310. https://doi.org/10.1016/j.lindif.2010.11.01 7

Meijer, P. C., de Graaf, G., \& Meirink, J. (2011). Key experiences in student teachers' development. Teachers and Teaching, 17(1), 115-129. https://doi.org/10.1080/13540602.2011.53 8502

Merriam, S. B., \& Tisdell, E. J. (2015). Qualitative research: A guide to design and implementation. John Wiley \& Sons.

Miles, M. B., Huberman, A. M., \& Saldaña, J. (2014). Qualitative data analysis: A methods sourcebook. Sage.

Mohamed, A. A., Castagna, A., Ranieri, A., \&
Sanità di Toppi, L. (2012). Cadmium tolerance in Brassica juncea roots and shoots is affected by antioxidant status and phytochelatin biosynthesis. Plant Physiology and Biochemistry, 57, 15-22. https://doi.org/10.1016/j.plaphy.2012.05.0 02

Patton, M. Q. (2002). Two decades of developments in qualitative inquiry. Qualitative Social Work, 1(3), 261-283. https://doi.org/10.1177/147332500200100 3636

Piantola, M. A. F., Moreno, A. C. R., Matielo, H. A., Taschner, N. P., Cavalcante, R. C. M., Khan, S., \& Ferreira, R. de C. C. (2018). Adopt a Bacterium - an active and collaborative learning experience in microbiology based on social media. Brazilian Journal of Microbiology, 49(4), 942-948.

https://doi.org/10.1016/j.bjm.2018.04.005

Rallis, S. F., \& Rossman, G. B. (2012). The research journey: Introduction to inquiry. Guilford Press.

Redmond, M., \& Bright, E. (2007). Gatekeeping in the academy: Lessons for Canadian social work educators from Young v. Bella. Canadian Social Work Review/Revue Canadienne de Service Social, 24(2), 167-181.

Roness, D. (2011). Still motivated? The motivation for teaching during the second year in the profession. Teaching and Teacher Education, 27(3), 628-638. https://doi.org/10.1016/j.tate.2010.10.016

Rustaman, N. (2002). Peranan praktikum dalam pembelajaran biologi. Universitas Pendidikan Indonesia.

Rutherford, G. (2016). Questioning special needs-ism: Supporting student teachers in troubling and transforming understandings of human worth. Teaching and Teacher Education, 56, 127-137. https://doi.org/10.1016/j.tate.2016.02.009

Rutherford, S. M., Limorenko, G., \& Shore, A. M. (2016). Correlations between deep, surface or strategic learning styles and perceptions of collaborative learning in higher education. Ireland International Conference on Education (IICE-2016).

Salawu, I. O., Okonkwo, U. M., Osuji, U. S. A., \& Adeoye, F. A. (2008). Teaching Practice Manual 1 (p. 24). National Open 
University of Nigeria.

Schon, D. A., \& DeSanctis, V. (1986). The reflective practitioner: How professionals think in action. The Journal of Continuing Higher Education, 34(3), 29-30. https://doi.org/10.1080/07377366.1986.10 401080

Schulz, R. (2005). The practicum: More than practice. Canadian Journal of Education / Revue Canadienne de l'éducation, 28(1/2), 147. https://doi.org/10.2307/1602158

Seferoğlu, G. (2006). Teacher candidates' reflections on some components of a preservice English teacher education programme in Turkey. Journal of Education for Teaching, 32(4), 369-378. https://doi.org/10.1080/026074706009819 53

Springer, L., Stanne, M. E., \& Donovan, S. S. (1999). Effects of small-group learning on undergraduates in science, mathematics, engineering, and technology: A metaanalysis. Review of Educational Research, 69(1), 21-51. https://doi.org/10.3102/003465430690010 21

Stake, R. E. (1995). The art of case study research. Sage.

Stewart, F. (2005). Horizontal inequalities: A neglected dimension of development. In Wider Perspectives on Global Development (pp. 101-135). Palgrave Macmillan UK. https://doi.org/10.1057/9780230501850_5

Sugiharto, B., Corebima, A. D., \& Susilo, H. (2018). A comparison of types of knowledge of cognition of preservice biology teachers. Asia-Pacific Forum on Science Learning \& Teaching, 19(1), 116.

Swan, K., Shen, J., \& Hiltz, S. R. (2019). Assessment and collaboration in online learning. Online Learning, 10(1). https://doi.org/10.24059/olj.v10i1.1770

Szklarski, A., Colnerud, G., \& Karlsson, I. (2008). Alltid redo: Lärarstudenters handlingsberedskap för varierande uppgifter i klassrummet. Linköping University Electronic Press.

Taguchi, H. L. (2007). Deconstructing and transgressing the theory-Practice dichotomy in early childhood education.
Educational Philosophy and Theory, 39(3), 275-290.

https://doi.org/10.1111/j.1469-

5812.2007.00324.x

Timmis, K., Cavicchioli, R., Garcia, J. L., Nogales, B., Chavarría, M., Stein, L., McGenity, T. J., Webster, N., Singh, B. K., Handelsman, J., Lorenzo, V., Pruzzo, C., Timmis, J., Martín, J. L. R., Verstraete, W., Jetten, M., Danchin, A., Huang, W., Gilbert, J., ... Harper, L. (2019). The urgent need for microbiology literacy in society. Environmental Microbiology, 21(5), 1513-1528.

https://doi.org/10.1111/1462-2920.14611

Tuli, F., \& File, G. (2010). Practicum experience in teacher education. Ethiopian Journal of Education and Sciences, 5(1). https://doi.org/10.4314/ejesc.v5i1.56316

United Nations Educational Scientific and Cultural Organization. (2005). Towards knowledge societies. Unesco.

van Hout-Wolters, B., Simons, R.-J., \& Volet, S. (2000). Active learning: Self-directed learning and independent work. In New Learning (pp. 21-36). Springer Netherlands. https://doi.org/10.1007/0306-47614-2_2

Vick, M. (2006). "It's a Difficult Matter"1: Historical perspectives on the enduring problem of the practicum in teacher preparation. Asia-Pacific Journal of Teacher Education, 34(2), 181-198. https://doi.org/10.1080/135986606007205 79

Wentworth, N., Graham, C. R., \& Tripp, T. (2008). Development of teaching and technology integration: Focus on pedagogy. Computers in the Schools, 25(1-2), 64-80. https://doi.org/10.1080/073805608021577 82

Wijaya, T. T., Ying, Z., Purnama, A., \& Hermita, N. (2020). Indonesian students' learning attitude towards online learning during the coronavirus pandemic. Psychology, Evaluation, and Technology in Educational Research, 3(1). https://doi.org/10.33292/petier.v3i1.56

Wimmer, R. (2008). A multi-disciplinary study of field experiences: possibilities for teacher education. Journal of Educational Thought, 42(3). 
https://doi.org/10.11575/jet.v42i3.52437

Wyss, V. L., Siebert, C. J., \& Dowling, K. A. (2012). Structuring effective practicum experiences for pre-service teachers. Education, 132(3), 600-607.

Yan, C., \& He, C. (2010). Transforming the existing model of teaching practicum: a study of Chinese EFL student teachers' perceptions. Journal of Education for Teaching, 36(1), 57-73. https://doi.org/10.1080/026074709034620 65

Yayli, D. (2008). Theory-practice dichotomy in inquiry: Meanings and preservice teachermentor teacher tension in Turkish literacy classrooms. Teaching and Teacher Education, 24(4), 889-900.

https://doi.org/10.1016/j.tate.2007.10.004
Yin, R. K. (2009). Case study research: Design and methods (5th ed.). Sage Publications, Inc.

Yin, R. K. (2017). Case study research and applications: Design and methods. Sage publications.

Zeichner, K. M. (1993). Educating teachers for cultural diversity. National Center for Research on Teacher Learning, Michigan State University

Zeichner, K. M., \& Conklin, H. G. (2008). Teacher education programs as sites for teacher preparation. In M. Cochran-Smith, S. Feiman-Nemser, D. J. McIntyre, \& K. E. Demers (Eds.), Handbook of research on teacher education: Enduring questions in changing contexts (p. 269). Routledge. 